\title{
Deteksi Citra Uang Kertas dengan Fitur RGB Menggunakan K-Nearest Neighbor
}

\author{
Andhika Ryan Pratama', Muhammad Mustajib², Aryo Nugroho ${ }^{3}$ \\ Sistem Informasi, Fakultas Ilmu Komputer \\ Universitas Narotama Surabaya \\ Surabaya, Indonesia \\ e-mail: ${ }^{1}$ andhikarp4@gmail.com, ${ }^{2}$ ajibmustajib14@gmail.com, ${ }^{3}$ aryo.nugroho@ narotama.ac.id \\ Diajukan: 11 Januari 2020; Direvisi: 18 Maret 2020; Diterima: 31 Maret 2020
}

\begin{abstract}
Abstrak
Mesin pendeteksi uang kertas menjadi salah satu objek yang diperhatikan untuk diteliti dan dikembangkan. Mesin pendeteksi uang kertas Indonesia yang ditemukan seperti di stasiun kereta api di suatu kota, terdapat kegagalan dalam mengenali nilai uang kertas tertentu. Tujuan dari penelitian ini adalah membangun model dari pengenalan nilai uang kertas menggunakan $K$-Nearest Neighbor $(K N N)$ yang merupakan metode yang paling sederhana dan paling penting dalam pengenalan pola, hal ini ditunjukkan pada akurasi yang diperoleh lebih tinggi dibandingkan metode lainnya seperti Artificial Neural Networks (ANN) dan Feedforward Neural Network (FNN). Model yang diusulkan menggunakan ekstraksi fitur, terdapat beberapa fitur yang digunakan untuk pengenalan uang kertas seperti yang pernah dilakukan menggunakan ekstraksi fitur tekstur. Penelitian ini menggunakan ekstraksi fitur warna. Warna memberikan informasi yang berarti dan nilai-nilai yang penting dalam proses mendeskripsikan suatu objek. Warna yang digunakan adalah Red, Green, Blue (RGB). Hasil disajikan pada dataset 40 gambar uang kertas yang terdiri dari pecahan 2000 rupiah keluaran lama, 2000 rupiah keluaran baru, 5000 rupiah keluaran lama, dan 5000 rupiah keluaran baru. Pendekatan yang diusulkan terlihat kinerja yang cukup baik dengan menggunakan metode KNN. Dari 16 data uji menunjukkan 15 objek uang kertas berhasil dideteksi dengan benar. Akurasi yang dihasilkan sebesar 93,7\% dengan nilai $K=5$.
\end{abstract}

Kata kunci: Deteksi, RGB, Warna, K-Nearest Neighbor (KNN), Uang kertas.

\begin{abstract}
The banknote detection machine is one of the objects to be considered for research and development. Indonesian banknote detection machines found like at a train station in a city have failed to recognize the value of certain banknotes. The purpose of this study is to build a model of introducing banknotes using K-Nearest Neighbor (KNN) which is the simplest and most important method of pattern recognition, this is shown in the accuracy obtained is higher than other methods such as artificial neural networks ( ANN) and feedforward Neural Network (FNN). The proposed model uses feature extraction, there are several features used for the introduction of banknotes, such as what has been done using texture feature extraction, this study uses color feature extraction, color provides meaningful information and values that are important in the process of describing an object. The colors used are Red, Green, Blue $(R G B)$. The results are presented in a dataset of 40 banknote drawings consisting of 2,000 rupiah of the old output, 2000 rupiah of the new output, 5000 rupiah of the old output, and 5000 rupiah of the new output. The proposed approach looks good enough performance using the KNN algorithm, from 16 test data showing 15 object banknotes were detected correctly, the resulting accuracy of $93.7 \%$ with a value of $K=$ 5 .
\end{abstract}

Keywords: Detection, RGB, Color, K-Nearest Neighbor (KNN), Banknotes.

\section{Pendahuluan}

Alat pembayaran yang sering digunakan oleh seluruh manusia hampir dalam setiap penjuru dunia salah satunya adalah uang kertas. Pasalnya, uang tersebut merupakan alat untuk transaksi dalam jual beli barang dan jasa [1]. Bank Indonesia mengeluarkan berbagai model dan nilai uang kertas, sehingga masyarakat Indonesia bertransaksi dengan uang kertas yang berbeda-beda. Tidak hanya masyarakat sekitar yang menggunakan uang kertas sebagai alat transaksinya, perusahaan besar juga menggunakan uang kertas 
untuk berlangsungnya proses bisnis mereka, salah satunya adalah perbankan. Secara umum, perbankan menyimpan atau meminjamkan uang kepada pelanggannya.

Perkembangan teknologi di dunia ini berpengaruh besar terhadap kemudahan aktivitas seseorang yang menjadi lebih terbantu. Berbagai sistem bermunculan dengan automasinya pada zaman perkembangan teknologi ini, bahkan penerapan dari sistem yang terautomasi dalam kehidupan telah banyak memberikan kemudahan dan membantu dalam pekerjaan [2]. Salah satu kemudahan yang dirasakan oleh manusia adalah dengan adanya mesin untuk mendeteksi atau mengenal nilai uang kertas. Pengenalan pada suatu objek adalah bidang yang sangat penting dan sangat diperhatikan dalam pengenalan pola. Hal tersebut dapat mengenal berbagai jenis objek dalam kehidupan nyata misalnya teks dalam dokumen, iris pada mata seseorang, pelat kendaraan, wajah seseorang, dan sebagainya. Pengenalan nilai uang kertas juga sama pentingnya dengan pengenalan objek lain [3]. Mesin pendeteksi nilai uang kertas menjadi salah satu objek yang diperhatikan untuk diteliti dan dikembangkan [4].

Nilai uang kertas rupiah di Indonesia sangat beragam dan terlihat sangat berbeda. Misalnya, ukuran kertas yang bervariasi, warna yang berbeda, dan pola yang berbeda. Orang harus mengingat visual dari setiap uang kertas tersebut. Hal ini dapat menyebabkan pengenalan uang kertas yang salah sehingga orang membutuhkan sistem yang efisien dan tepat untuk membantu pekerjaan mereka [5]. Tujuan dari sistem pengenalan uang kertas adalah mengenali nilai uang kertas secara otomatis dengan menggunakan berbagai teknik dan metode. Sistem pengenalan nilai uang kertas dapat digunakan di banyak tempat seperti bank, konter tiket, layanan penukaran mata uang, hotel, toko, mesin teller otomatis, dan lain-lain [6]. Tetapi pada umumnya, pengenalan nilai uang kertas menggunakan perangkat keras khusus. Orang biasa pada umumnya tidak selalu memiliki akses untuk menggunakan alat tersebut. Oleh karena itu, dibutuhkan sistem terkomputerisasi yang dapat mengenali uang kertas dengan menggunakan citra [4].

Mesin pendeteksi uang kertas Indonesia yang ditemukan seperti di stasiun kereta api di suatu kota terdapat kegagalan dalam mengenali nilai uang kertas tertentu, sehingga tujuan dari penelitian ini adalah membangun sistem untuk mengenal uang kertas rupiah menggunakan ekstraksi fitur. Ekstraksi fitur memiliki prosedur yang sangat tinggi untuk pengenalan nilai uang kertas yang dampaknya berlangsung pada desain dan kinerja dari classifier [7].

Penelitian ini menggunakan fitur warna pada pengenalan nilai uang kertas rupiah. Warna memberikan informasi yang berarti dan nilai-nilai yang penting dalam proses mendeskripsikan suatu objek [8]. Warna yang digunakan adalah Red, Green, Blue (RGB). Proses deteksi nilai uang kertas menggunakan nilai dari ekstraksi fitur Red, Green, Blue (RGB), kemudian hasil ekstraksi fitur digunakan untuk mengklasifikasikan nilai uang kertas dengan metode K-Nearest Neighbor (KNN) sebagai pendeteksian nilai uang kertas. Terdapat beberapa metode yang digunakan untuk klasifikasi seperti metode Nä̈ve Bayes [9], namun pada metode Nä̈ve Bayes didasarkan pada probabilitas atau peluang bersyarat [10], berbeda dengan metode KNN yang menghitung jarak terdekat untuk pengklasifikasiannya. Metode K-Nearest Neighbor merupakan metode yang paling penting dan paling sederhana dalam pengenalan pola, hal ini ditunjukkan pada akurasi yang diperoleh lebih tinggi dibandingkan dengan metode lainnya seperti Artificial Neural Networks (ANN) dan Feedforward Neural Network (FNN) [11].

Penelitian terkait pendeteksian nilai uang kertas dengan berbagai fitur telah dilakukan, seperti penelitian [11] menggunakan fitur tekstur Gray-Level Co-Occurrence Matrix (GLCM) dengan metode $\mathrm{KNN}$ dengan nilai $\mathrm{K}=1$. Harapan dari penelitian yang dilakukan membangun model deteksi nilai uang kertas rupiah menggunakan ekstraksi fitur warna dan menggunakan metode KNN dengan nilai K lebih besar dari penelitian sebelumnya menghasilkan akurasi yang cukup baik yang dapat mendeteksi nilai uang kertas rupiah dengan benar dan tepat serta bermanfaat bagi pihak yang memerlukan.

\section{Metode Penelitian}

Perencanaan alur penelitian merupakan serangkaian tahapan untuk menyelesaikan penelitian ini. Tahapan penelitian digambarkan pada Gambar 1 di bawah ini.

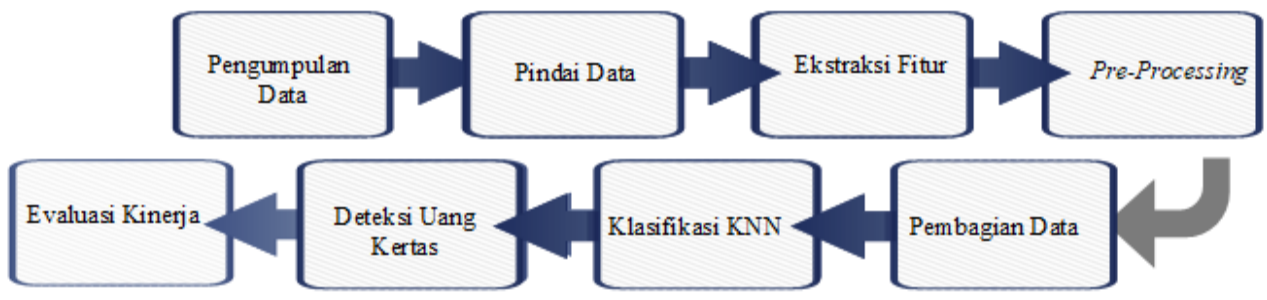

Gambar 1. Tahapan penelitian. 


\subsection{Pengumpulan Data}

Data yang digunakan adalah uang kertas yang dikeluarkan oleh Bank Indonesia. Penelitian ini menggunakan uang kertas pecahan 2000 model baru, 2000 model lama, 5000 model baru, 5000 model lama. Jumlah dari setiap uang kertas adalah 10 dipilih dari mulai yang kualitas bagus sampai kualitas kusut terlipat-lipat karena faktor lama atau pergerakan uang tersebut dari satu tangan ke tangan yang lainnya. Total dari uang kertas adalah berjumlah 40.

\subsection{Memindai Data}

Tahap pindai dilakukan untuk pengambilan citra uang kertas menggunakan fitur warna RGB. Pindai dilakukan dengan menggunakan alat pemindai dokumen (scanner) agar keaslian dan warna pada uang kertas menjadi lebih jelas.

Pada uang kertas terdapat dua sisi yang berbeda yaitu sisi muka dan sisi belakang, sehingga dilakukan pindai terhadap uang kertas dengan dua sisi yang berbeda. Pengulangan pindai dilakukan sebanyak tiga kali. Pindai yang pertama pada alat pemindai tidak diberi bobot di atasnya, pada tahap pindai yang kedua kalinya diberi bobot pada atas alat pemindai dengan beban yang sedang, tahapan pindai yang ketiga diberi beban lebih berat dari pada tahapan yang kedua. Pindai dengan pengulangan tiga kali dilakukan untuk mengetahui apakah setiap dari tahapan pindai yang berbeda mempunyai hasil yang berbeda pula.

\subsection{Ekstraksi Fitur}

Ekstraksi Fitur diperlukan untuk mengetahui suatu citra. Teknik ekstraksi fitur yang digunakan adalah dengan mengekstrak citra warna RGB (Red-Green-Blue). Pengambilan fitur warna RGB menggunakan aplikasi Design Graphic. Uang yang telah dipindai di-import ke dalam aplikasi dan diseleksi pada uang kertas tersebut dan secara otomatis aplikasi mengeluarkan fitur warna RGB pada uang kertas. Setiap uang kertas dilakukan dua tahapan ekstraksi fitur, karena pada uang kertas terdapat dua sisi yang berbeda yaitu dari sisi muka dan dari sisi belakang.

\subsection{Preprocessing}

Hasil dari ekstraksi fitur pada uang kertas adalah nilai dari setiap fitur warna Red-Green-Blue. Terdapat nilai yang sama pada nilai fitur RGB sehingga dilakukan proses pembersihan terhadap data yang sama, selain itu data diproses dengan mendekatkan pola-pola dalam satu kelas yang sama dan menjauhkan pola-pola yang berbeda kelas sehingga pola-pola akan terkelompok rapi dan terpisah dari kelas lain [10].

\subsection{Pembagian Data}

Pembagian data digunakan untuk pengklasifikasian terhadap hasil pendeteksian uang kertas. Pada model klasifikasi dibutuhkan suatu input data pembelajaran (data training) dan juga data testing. Data pembelajaran akan menghasilkan model yang nantinya akan dijadikan model pengklasifikasian terhadap data yang baru. Pembagian data dilakukan secara random untuk penentuan data pembelajaran dan juga data testing. Pembagian data bisa dilihat pada Gambar 2 di bawah ini.

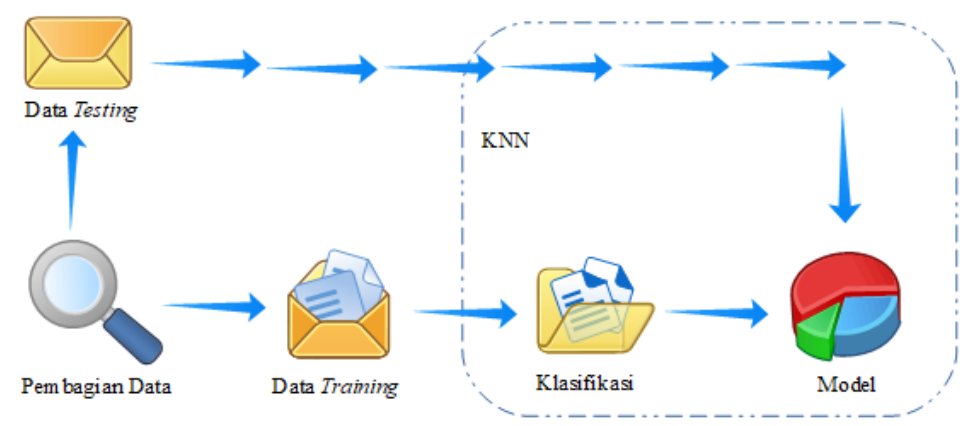

Gambar 2. Pembagian data.

\subsection{Klasifikasi K-Nearest Neighbor}

KNN termasuk algoritma klasifikasi supervised learning yang mengklasifikasikan suatu objek ke dalam kelas baru berdasarkan data training dan atribut kelas [12]. Metode KNN pada data testing akan membandingkan data yang sudah dipelajari yaitu data pembelajaran (data training). Metode ini sangat 
bergantung pada nilai $\mathrm{K}$, sehingga salah satu tahap awal adalah menentukan nilai K. Selanjutnya menghitung jarak dari objek baru terhadap data training, sebelum ditentukan kategori dari objek baru berdasarkan mayoritas pada nilai K dilakukan urutan data dari data testing yang mempunyai jarak terkecil dari data training. Proses KNN digambarkan pada Gambar 3 [13].

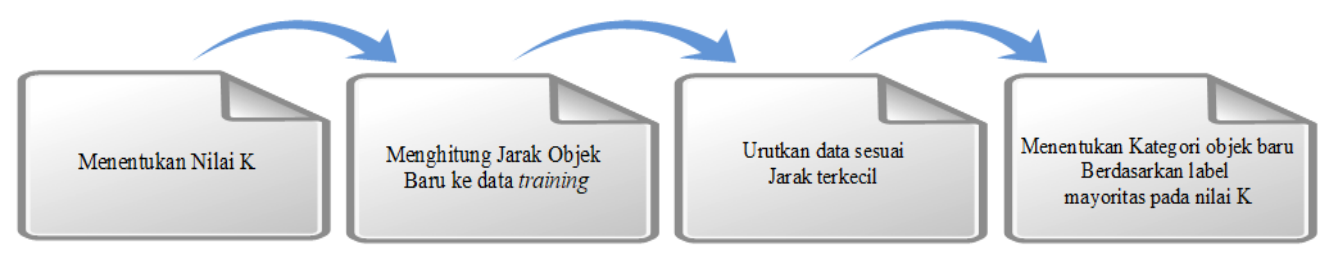

Gambar 3. Proses algoritma KNN

Dari tahapan algoritma KNN yang ada pada Gambar 3, proses algoritma KNN bila ditunjukkan dalam bentuk Pseudocode digambarkan pada Gambar 4.

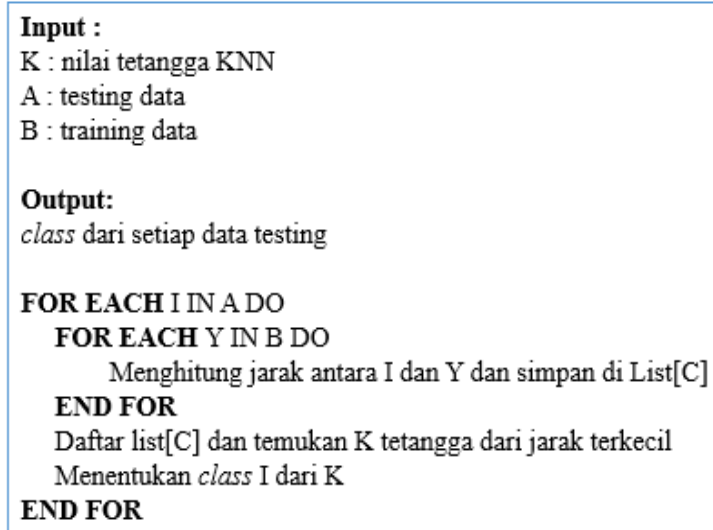

Gambar 4. Pseudocode algoritma KNN

\subsection{Deteksi Uang Kertas}

Deteksi dilakukan pada file uang kertas yang telah dipindai sebagai data baru yang akan ditentukan uang kertas tersebut termasuk dalam salah satu dari empat kategori kelas (class) yang sebelumnya telah dilakukan data pembelajaran (data training). Penelitian ini menggunakan aplikasi $\mathrm{R}$ untuk mendeteksi. kategori dari pendeteksian uang kertas yaitu uang 5000A untuk nilai uang kertas 5000 model lama, 5000B untuk nilai uang kertas 5000 model baru, 2000A untuk nilai uang ketas 2000 model lama dan 2000B untuk nilai uang kertas model baru.

\subsection{Evaluasi Kinerja}

Pada tahap ini bertujuan untuk mengevaluasi dan menganalisis model yang digunakan pada penelitian. Proses perhitungan akurasi hasil klasifikasi menggunakan Confusion matrix. Confusion matrix merupakan sebuah tabel yang berisi hasil yang diprediksi dengan benar dan juga tidak benar oleh permodelan kalsifikasi, tabel ini diperlukan untuk menentukan kinerja dari model klasifikasi. Contoh tabel confusion matrix dapat dilihat pada Tabel 1.

Tabel 1. Tabel Confusion Matrix.

\begin{tabular}{ccc}
\hline $\mathbf{N}=\mathbf{7}$ & Prediksi class $\mathbf{1}$ & Prediksi class $\mathbf{2}$ \\
\hline Actual class 1 & $\mathrm{TN}=3$ & $\mathrm{FP}=2$ \\
\hline Actual class 2 & $\mathrm{FN}=0$ & $\mathrm{TP}=2$ \\
\hline
\end{tabular}

Dalam confusion matrix ada beberapa istilah yang digunakan, yaitu [14] :

- True positive (TP): jumlah data positif yang diklasifikasikan dengan benar.

- True Negative (TN): jumlah data negatif yang diklasifikasikan dengan benar.

- False Positive (FP): jumlah data yang benar yang diklasifikasikan sebagai data yang salah. 
- False Negative (FN): jumlah data yang salah dikalsifikasikan sebagai data yang benar.

Akurasi dapat dihitung dengan persamaan sebagai berikut :

$$
\frac{T P+T N}{T P+T N+F P+F N}
$$

\section{Hasil dan Pembahasan}

Hasil dari penelitian adalah pengujian data pada tahap klasifikasi menggunakan metode yang telah ditentukan. Pengujian dilakukan untuk mengetahui pendeteksian pada nilai uang kertas rupiah yang telah diekstraksi fitur warnanya. Dataset yang digunakan adalah data yang telah di-preprocessing sebelumnya dibuat data pembelajaran (training) dan juga data testing untuk pendeteksian nilai uang kertas.

\subsection{Hasil Pindai Uang Kertas}

Uang kertas memiliki dua sisi yang berbeda, sehingga tahap pindai dilakukan dua kali terhadap sisi-sisi tersebut untuk pengambilan ekstraksi fitur warna. Contoh pindai uang kertas dengan tiga kali percobaan ditunjukkan pada Tabel 2.

Tabel 2. Pindai uang kertas dengan tiga kali percobaan.

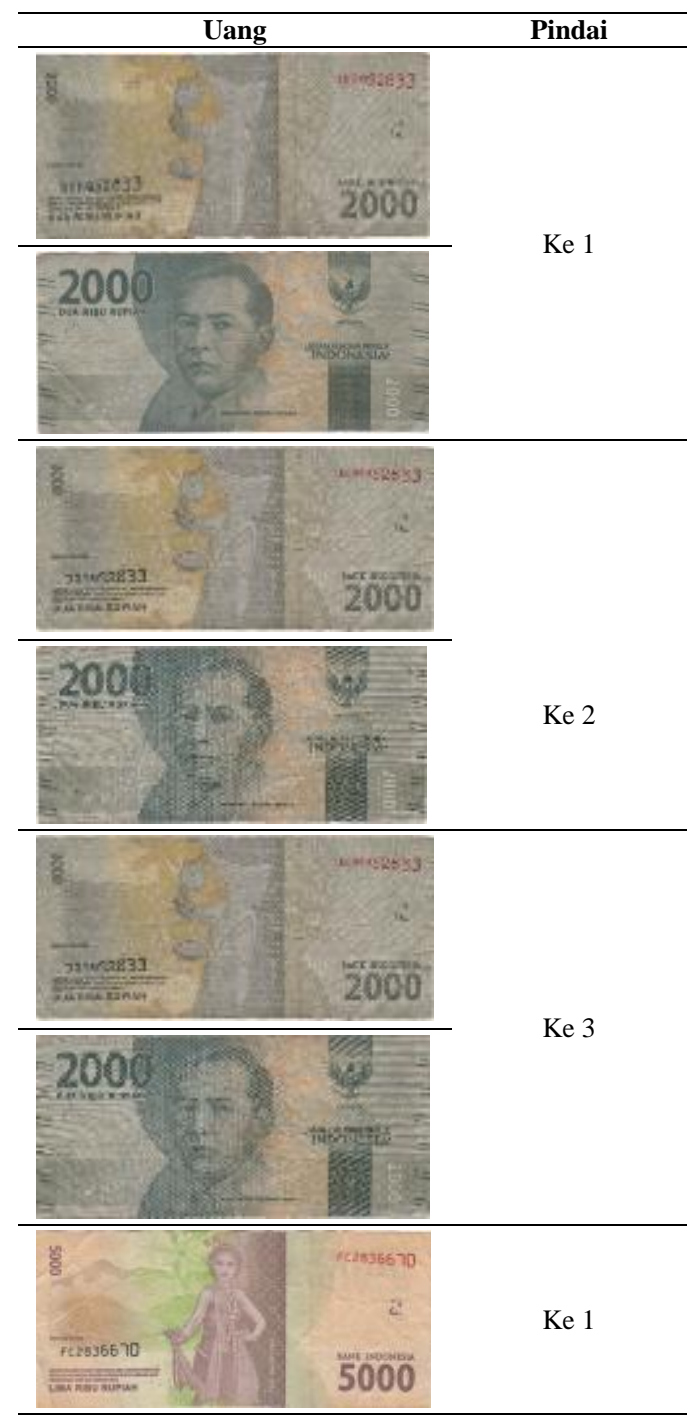




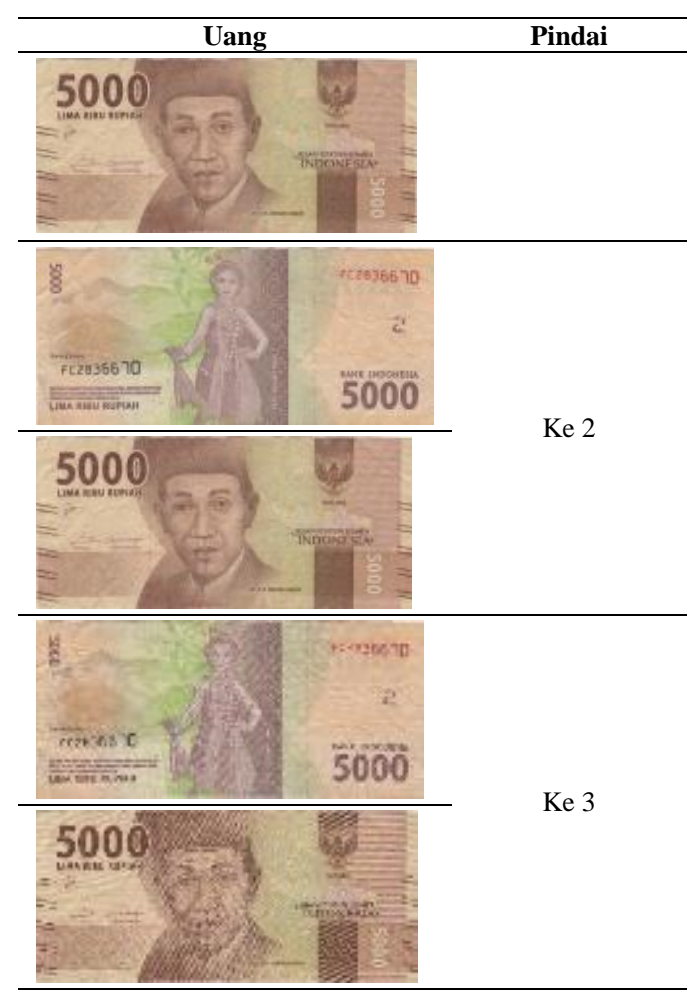

Hasil pindai dilakukan pengulangan sebanyak tiga kali menghasilkan nilai yang berbeda untuk fitur warna RGB, namun ada juga yang terdapat nilai yang sama antara pindai ke 1 dan ke 2 atau pindai ke 2 dan pindai ke 3 .

\subsection{Hasil Ekstraksi Fitur}

Tahap ekstraksi fitur pada uang kertas dengan mengeluarkan nilai dari RGB (Red, Green, Blue). Contoh nilai dari ekstraksi fitur warna dengan menggunakan aplikasi Design Graphic ditunjukkan pada Tabel 3.

Tabel 3. Hasil data nilai ekstraksi.

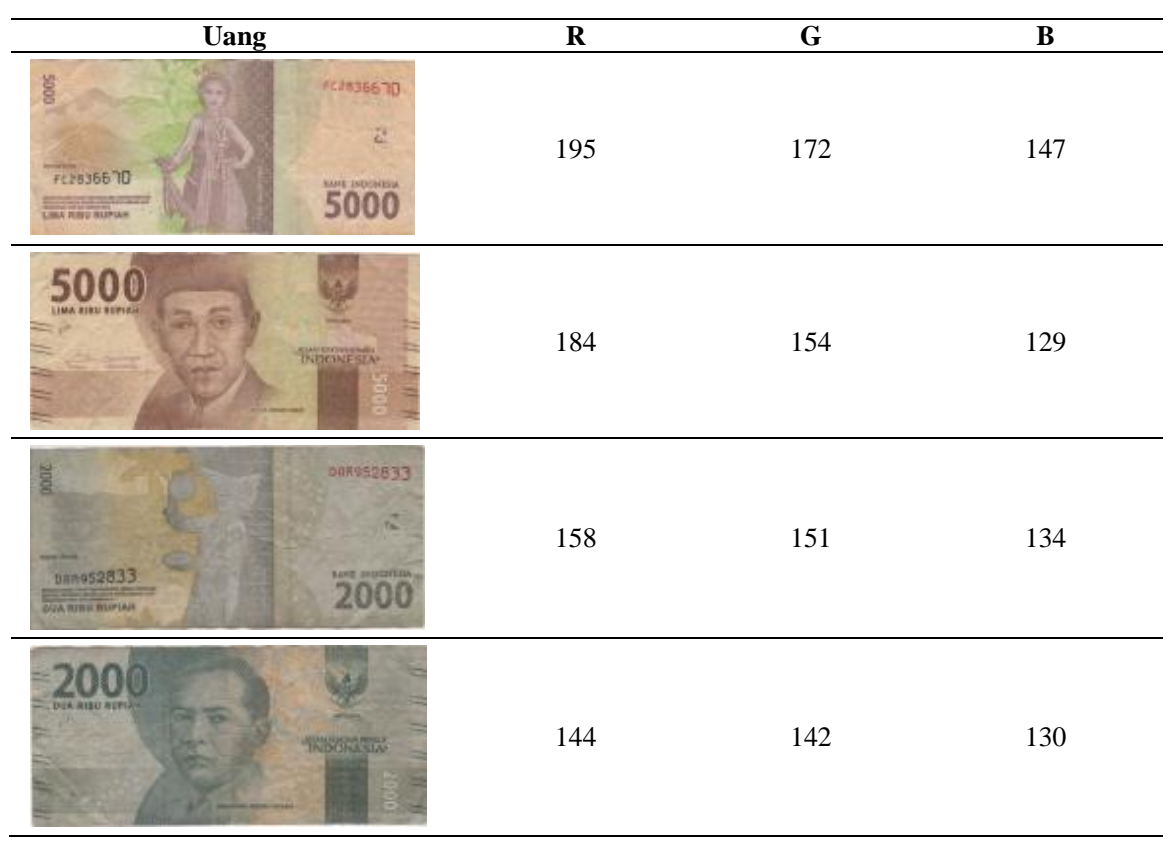




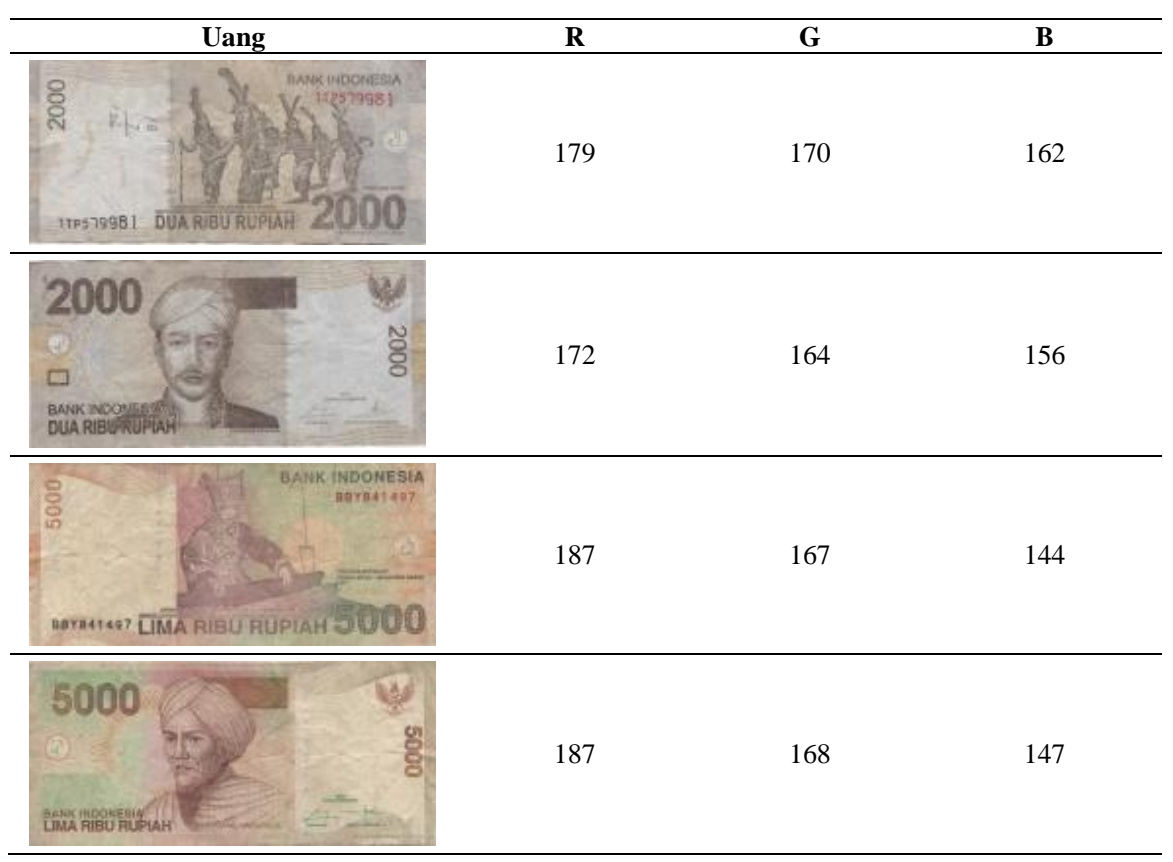

\subsection{Hasil Preprocessing}

Uang kertas yang telah dipindai dengan pengulangan tiga kali terdapat nilai yang sama sehingga dilakukan pembersihan terhadap nilai yang sama. Pembersihan data ditunjukkan pada Gambar 5.

\begin{tabular}{|l|c|c|c|c|c|c|c|c|c|}
\hline \multicolumn{10}{|c|}{ Mata Uang Kertas 5000 Keluaran Lama } \\
\hline & \multicolumn{1}{|c|}{ Pindai Ke 1 } & \multicolumn{3}{c|}{ Pindai ke 2 } & \multicolumn{3}{c|}{ Pindai ke 3 } \\
\hline Uang & $\mathbf{R}$ & $\mathbf{G}$ & $\mathbf{B}$ & $\mathbf{R}$ & $\mathbf{G}$ & $\mathbf{B}$ & $\mathbf{R}$ & $\mathbf{G}$ & $\mathbf{B}$ \\
\hline Uang 1 belakang & 187 & 167 & 144 & 188 & 167 & 145 & & & \\
\hline Uang 1 muka & 187 & 168 & 147 & 188 & 169 & 147 & & & \\
\hline Uang 2 belakang & 167 & 144 & 125 & 168 & 145 & 126 & & & \\
\hline Uang 2 muka & 168 & 145 & 126 & 168 & 145 & 125 & 168 & 146 & 125 \\
\hline Uang 3 belakang & 171 & 152 & 133 & 172 & 152 & 133 & 172 & 152 & 134 \\
\hline Uang 3 muka & 174 & 154 & 135 & 174 & 155 & 136 & 175 & 155 & 136 \\
\hline Uang 4 belakang & 185 & 163 & 142 & 186 & 163 & 142 & & & \\
\hline Uang 4 muka & 185 & 163 & 141 & 184 & 163 & 140 & 185 & 163 & 141 \\
\hline Uang 5 belakang & 195 & 172 & 147 & & & & & & \\
\hline Uang 5 muka & 195 & 177 & 153 & 195 & 177 & 152 & & & \\
\hline Uang 6 belakang & 163 & 139 & 119 & & & & 164 & 140 & 119 \\
\hline Uang 6 muka & 165 & 143 & 122 & & & & & & \\
\hline Uang 7 belakang & 193 & 171 & 148 & 195 & 172 & 148 & 194 & 171 & 148 \\
\hline Uang 7 muka & 192 & 173 & 151 & 193 & 174 & 151 & 192 & 173 & 150 \\
\hline Uang 8 belakang & 171 & 148 & 129 & 170 & 148 & 128 & 172 & 149 & 129 \\
\hline Uang 8 muka & 170 & 148 & 128 & 169 & 147 & 128 & 170 & 147 & 128 \\
\hline Uang 9 belakang & 186 & 166 & 145 & 188 & 167 & 146 & 187 & 166 & 145 \\
\hline Uang 9 muka & 186 & 165 & 145 & 188 & 166 & 146 & 187 & 165 & 145 \\
\hline Uang 10 belakang & 192 & 172 & 150 & & & & 193 & 173 & 150 \\
\hline Uang 10 muka & 190 & 173 & 151 & 190 & 173 & 152 & & & \\
\hline
\end{tabular}

Gambar 5. Pembersihan data.

Pada Gambar 5 terdapat nilai yang kosong dari RGB merupakan hasil pembersihan data yang sama. Selanjutnya mendekatkan pola-pola dalam satu kelas yang sama dan menjauhkan pola-pola yang berbeda kelas, hal ini ditunjukkan pada Gambar 6. 


\begin{tabular}{|c|c|c|c|}
\hline $\mathbf{R}$ & G & B & Uang \\
\hline 163 & 139 & 119 & $5000 \mathrm{~A}$ \\
\hline 164 & 140 & 119 & $5000 \mathrm{~A}$ \\
\hline 165 & 143 & 122 & $5000 \mathrm{~A}$ \\
\hline 167 & 144 & 125 & $5000 \mathrm{~A}$ \\
\hline 168 & 145 & 126 & $5000 \mathrm{~A}$ \\
\hline 168 & 145 & 125 & $5000 \mathrm{~A}$ \\
\hline 171 & 142 & 120 & $5000 \mathrm{~B}$ \\
\hline 172 & 142 & 119 & $5000 \mathrm{~B}$ \\
\hline 173 & 143 & 119 & $5000 \mathrm{~B}$ \\
\hline 174 & 141 & 118 & $5000 \mathrm{~B}$ \\
\hline 177 & 154 & 129 & $5000 B$ \\
\hline 177 & 146 & 122 & $5000 \mathrm{~B}$ \\
\hline 159 & 153 & 146 & $2000 \mathrm{~A}$ \\
\hline 159 & 146 & 136 & $2000 \mathrm{~A}$ \\
\hline 160 & 147 & 136 & $2000 \mathrm{~A}$ \\
\hline 160 & 145 & 132 & $2000 \mathrm{~A}$ \\
\hline 160 & 145 & 133 & $2000 \mathrm{~A}$ \\
\hline 162 & 147 & 133 & $2000 \mathrm{~A}$ \\
\hline 143 & 140 & 124 & $2000 \mathrm{~B}$ \\
\hline 144 & 142 & 130 & $2000 B$ \\
\hline 144 & 139 & 123 & $2000 B$ \\
\hline 144 & 142 & 129 & $2000 B$ \\
\hline 146 & 147 & 136 & $2000 B$ \\
\hline 148 & 150 & 137 & $2000 \mathrm{~B}$ \\
\hline
\end{tabular}

Gambar 6. Data dalam satu kelas.

Data dipisahkan menjadi empat kelas (class) sesuai jenis uang yang telah diekstraksi. Berikut penjelasan dari beberapa kelas (class) pada dataset :

- 5000A: Uang kertas nominal 5000 model lama.

- 5000B: Uang kertas nominal 5000 model baru.

- 2000A: Uang kertas nominal 2000 model lama.

- 2000B: Uang kertas nominal 2000 model baru.

Contoh dari dataset ditunjukkan pada Tabel 4.

Tabel 4. Hasil dataset.

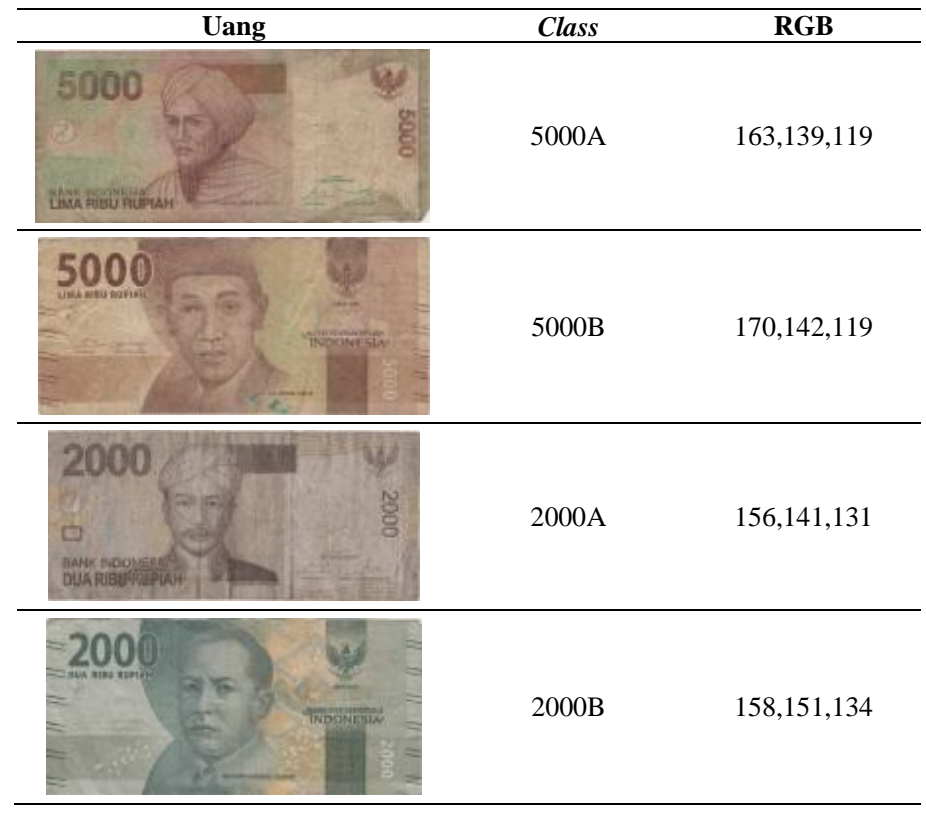

\subsection{Hasil Deteksi Uang kertas}

Hasil dari permodelan pengujian deteksi nilai uang kertas menggunakan 16 data uji yang dilakukan terhadap 160 data training. Proses deteksi dilakukan menggunakan metode K-Nearest Neighbor dengan nilai $\mathrm{K}=5$. Hasil dari pengujian deteksi menggunakan R programming ditunjukkan pada Gambar 7 . 


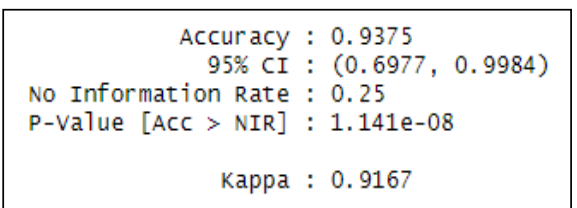

Gambar 7. Hasil Deteksi menggunakan K-Nearest Neighbor

Gambar 7 menunjukkan hasil akurasi model deteksi nilai uang kertas dengan fitur warna RGB dengan menggunakan K-Nearest Neighbor sebesar 93,7\%. Metode dari K-Nearest Neighbor digunakan untuk proses deteksi nilai uang kertas melakukan deteksi dengan cukup baik. Hasil deteksi uang kertas ditunjukkan pada Tabel 4.

Tabel 4. Hasil Deteksi Menggunakan KNN.

\begin{tabular}{ccc}
\hline Uang & class & Prediksi \\
\hline Uang 1 & $5000 \mathrm{~A}$ & 5000A \\
\hline Uang 2 & $5000 \mathrm{~A}$ & $5000 \mathrm{~A}$ \\
\hline Uang 3 & $5000 \mathrm{~A}$ & $5000 \mathrm{~A}$ \\
\hline Uang 4 & $5000 \mathrm{~A}$ & $5000 \mathrm{~A}$ \\
\hline Uang 5 & $5000 \mathrm{~B}$ & $5000 \mathrm{~B}$ \\
\hline Uang 6 & $5000 \mathrm{~B}$ & $5000 \mathrm{~B}$ \\
\hline Uang 7 & $5000 \mathrm{~B}$ & $5000 \mathrm{~B}$ \\
\hline Uang 8 & $5000 \mathrm{~B}$ & $5000 \mathrm{~A}$ \\
\hline Uang 9 & $2000 \mathrm{~A}$ & $2000 \mathrm{~A}$ \\
\hline Uang 10 & $2000 \mathrm{~A}$ & $2000 \mathrm{~A}$ \\
\hline Uang 11 & $2000 \mathrm{~A}$ & $2000 \mathrm{~A}$ \\
\hline Uang 12 & $2000 \mathrm{~A}$ & $2000 \mathrm{~A}$ \\
\hline Uang 13 & $2000 \mathrm{~B}$ & $2000 \mathrm{~B}$ \\
\hline Uang 14 & $2000 \mathrm{~B}$ & $2000 \mathrm{~B}$ \\
\hline Uang 15 & $2000 \mathrm{~B}$ & $2000 \mathrm{~B}$ \\
\hline Uang 16 & $2000 \mathrm{~B}$ & $2000 \mathrm{~B}$ \\
\hline
\end{tabular}

Tabel 4 menunjukkan hasil deteksi dari 16 data uji, 15 objek uang kertas berhasil dideteksi dengan benar. Kesalahan deteksi terdapat pada satu uang kertas yaitu uang 8. Evaluasi hasil dengan menggunakan nilai dari confusion matrix ditunjukkan pada Tabel 5.

Tabel 5. Hasil Confusion Matrix.

\begin{tabular}{ccccc}
\hline N=16 & \multicolumn{4}{c}{ Class Sebenarnya } \\
\hline Prediksi & 2000A & 2000A & 5000A & 5000B \\
\hline 2000A & 4 & 0 & 0 & 0 \\
\hline 2000B & 0 & 4 & 0 & 0 \\
\hline $5000 \mathrm{~A}$ & 0 & 0 & 3 & 1 \\
\hline $5000 \mathrm{~B}$ & 0 & 0 & 0 & 4 \\
\hline
\end{tabular}

Pada tabel 5 menunjukkan hasil yang sama dengan tabel 4, terdapat 1 kesalahan prediksi nilai uang kertas yaitu pada baris 5. Nilai uang kertas pada kelas (class) sebenarnya adalah 5000B namun diprediksi dengan salah pada 5000A.

\section{Kesimpulan}

Model deteksi nilai uang kertas dengan fitur warna Red, Green, Blue (RGB) menggunakan metode K-Neareast Neighbor berhasil melakukan deteksi dengan cukup baik. Ekstraksi fitur warna RGB digunakan untuk pengenalan citra pada objek juga sebagai input untuk metode K-Nearest Neighbor dalam pendeteksian. Dari 16 data uji menunjukkan 15 objek uang kertas berhasil dideteksi dengan benar, terdapat kesalahan deteksi pada satu uang kertas. Hasil akurasi yang dihasilkan sebesar 93,7\% dengan nilai $\mathrm{K}=5$. Akurasi yang didapat dari pembangunan model deteksi nilai uang kertas menggunakan fitur warna RGB dan metode KNN bisa bermanfaat bagi pihak yang memerlukan.

\section{Daftar Pustaka}

[1] J. F. Fauzi, H. Tolle, and R. K. Dewi, "Implementasi Metode RGB To HSV pada Aplikasi Pengenalan Mata Uang Kertas Berbasis Android untuk Tuna Netra," J. Pengemb. Teknol. Inf. dan Ilmu Komput., vol. 2, no. 6, pp. 2319-2325, 2018. 
[2] J. Fathani, U. Sunarya, and I. N. A. Ramatryana, “Aplikasi Identifikasi Dan Konversi Mata Uang Kertas Asing Terhadap Rupiah Dengan Metoda Local Binary Pattern ( Lbp ) Berbasis Android," $e$ Proceeding Eng., vol. 1, no. 1, pp. 363-371, 2014.

[3] M. Sarfraz, “An Intelligent Paper Currency Recognition System," Procedia Comput. Sci., vol. 65, no. International Conference on Communication, Management and Information Technology, pp. 538545, 2015.

[4] C. Page and S. H. M. G, "Paper Currency Detection based Image Processing Techniques: A review paper," J. Al-Qadisiyah Comput. Sci. Math., vol. 10, no. 1, pp. 1-8, 2018.

[5] V. Abburu, S. Gupta, S. R. Rimitha, M. Mulimani, and S. G. Koolagudi, "Currency recognition system using image processing,” 2017 10th Int. Conf. Contemp. Comput. IC3 2017, vol. 2018-Janua, pp. 16, 2018.

[6] J. Akter, M. K. Hossen, and M. S. A. Chowdhury, "Bangladeshi Paper Currency Recognition System Using Supervised Learning," Int. Conf. Comput. Commun. Chem. Mater. Electron. Eng. IC4ME2 2018, pp. 1-4, 2018.

[7] G. Ibrahim Raho, A. Al-Khiat, and A. H. Al-Hamami, "Cash Currencies Recognition Using k-Nearest Neighbor Classifier,” Int. J. Web Semant. Technol., vol. 6, no. 4, pp. 11-21, 2015.

[8] I. Abu Doush and S. AL-Btoush, "Currency recognition using a smartphone: Comparison between color SIFT and gray scale SIFT algorithms," J. King Saud Univ. - Comput. Inf. Sci., vol. 29, no. 4, pp. 484-492, 2017.

[9] E. B. Santoso and A. Nugroho, "Analisis Sentimen Calon Presiden Indonesia 2019 Berdasarkan Komentar Publik Di Facebook,” Eksplora Inform., vol. 9, no. 1, pp. 60-69, 2019.

[10] Suyanto, Data Mining Untuk Klasifikasi dan Klasterisasi Data. Informatika Bandung., 2019.

[11] K. N. N. Hlaing and A. K. Gopalakrishnan, "Myanmar paper currency recognition using GLCM and k-NN," 2016 2nd Asian Conf. Def. Technol. ACDT 2016, pp. 67-72, 2016.

[12] J. A. Septian, T. M. Fahrudin, and A. Nugroho, "Analisis Sentimen Pengguna Twitter Terhadap Polemik Persepakbolaan Indonesia Menggunakan Pembobotan TF - IDF dan K - Nearest Neighbor," J. Intell. Syst. Comput., pp. 43-49, 2019.

[13] F. Liantoni, "Klasifikasi Daun Dengan Perbaikan Fitur Citra Menggunakan Metode K-Nearest Neighbor," J. Ultim., vol. 7, no. 2, pp. 98-104, 2016.

[14] F. Y. Manik and K. S. Saragih, "Klasifikasi Belimbing Menggunakan Naïve Bayes Berdasarkan Fitur Warna RGB,” IJCCS (Indonesian J. Comput. Cybern. Syst., vol. 11, no. 1, p. 99, 2017. 